\title{
INITIAL DEVELOPMENT AND SAMPLE DIMENSIONING OF RUBBER TREE CLONES
}

\author{
DESENVOLVIMENTO INICIAL E DIMENSIONAMENTO AMOSTRAL EM CLONES \\ DE SERINGUEIRA
}

\author{
Victor Hugo Santi de OLIVEIRAㅜ; Gileno Brito de AZEVEDO'; Larissa Pereira RIBEIRO²; \\ Glauce Tais de Oliveira Souza AZEVEDO' ${ }^{1}$; Cassiano Garcia ROQUE ${ }^{1}$; Tays Silva BATISTA ${ }^{1}$, \\ Paulo Eduardo TEODORO' \\ 1. Universidade Federal de Mato Grosso do Sul - UFMS, Campus de Chapadão do Sul - CPCS, Chapadão do Sul, MS, Brasil. \\ eduteodoro@ hotmail.com; 2. Universidade Federal de Viçosa, Viçosa, MG, Brasil.
}

\begin{abstract}
The current success of rubber cultivation is related to the use of clones adapted to different edaphoclimatic regions. Hence, it is important to evaluate variables that are correlated with yield. However, a common problem is choosing the plot dimensions where these variables will be measured. In view of the above, the objective of this work was to evaluate the initial development of two rubber tree clones and to determine the ideal sample unit size to characterize trunk circumference, tree height and bark thickness. The variables circumference at breast height (CBH), total height (Ht) and bark thickness (BT) were measured in seven plots of $680.4 \mathrm{~m}^{2}$, in addition to determining the plot size to satisfactorily sample each of the variables measured in each clone, 52 months after planting. At 52 months, clone RRIM 937 showed better development than RRIM600 in relation to the analyzed variables. The ideal sample unit size is different for the variables in the following order: trunk circumference $>$ total height $>$ bark thickness. The measurement of plots with 15 trees is adequate to represent the variability of the analyzed variables, considering the acceptable error of $10 \%$.
\end{abstract}

KEYWORDS: Hevea brasiliensis. Forestry. Adaptation of clones.

\section{INTRODUCTION}

Rubber tree [Hevea brasiliensis (Willd. ex A.Juss.) Müll.Arg.], belongs to the Euphorbiaceae family, and is native to the Amazon region in Brazil, and other South American countries (COSTA et al., 2001; GONCALVES et al., 2001). It is the main source of natural rubber, a product widely used in pneumatic manufacturing and several other manufactured products (RIPPEL; BRAGANÇA, 2009; OLIVEIRA et al., 2014). Due to its great commercial importance and adaptive capacity to diverse climatic variations, it is cultivated worldwide in a large area of geographic distribution, extending from latitudes $24^{\circ} \mathrm{N}$ to $25^{\circ} \mathrm{S}$ (PILAU et al., 2007).

The current success of rubber cultivation is related to the use of clones adapted to different edaphoclimatic regions (CONFORTO et al., 2015). It is important to choose clones with high yield and precocity over its cycle (CONFORTO et al., 2011; 2015). In addition, studies are needed to better understand the interaction between developmental factors that determine yield, which involve genetic, ecological and physiological attributes and management practices adopted (GONÇALVES et al., 1994; CONFORTO et al., 2011).

Latex yield is correlated with plant morphological traits, such as stem circumference, plant height and bark thickness (GONÇALVES et al., 1984; ROQUE et al., 2006). Stem circumference and bark thickness are also important traits in setting the time to start latex exploration (CAVALCANTE; CONFORTO, 2013; VIRGENS FILHO, 2014). Thus, the measurement of these traits is important to evaluate the development and production of different genetic materials and to provide information supporting the definition of appropriate management techniques.

However, a common problem is choosing the plot dimensions where these variables will be measured. For both research development and forest inventory and management, the choice of plot size influences the data variability and hence their reliability (MUNIZ et al., 2009; BUSSAB; MORETTIN, 2011). The sample unit should have a size that is sufficient to include a representative number of trees, but small enough that the relationship between the establishment time of crop versus the working time in the data collection is not high, reducing costs of this activity (VAN LAAR; AKÇA, 2007).

Given the above, the objective of this study was to evaluate the initial development of rubber tree clones and to determine the ideal sample unit size to characterize the trunk circumference, tree height and bark thickness. 


\section{MATERIAL AND METHODS}

The experiment was done at Promissão Farm, located in the municipality of Paraíso das Águas (MS), in the Brazilian Cerrado, at the coordinates $19^{\circ} 03^{\prime} 08^{\prime \prime} \mathrm{S}$ and $52^{\circ} 58^{\prime} 06^{\prime \prime} \mathrm{W}$, with an altitude of approximately $600 \mathrm{~m}$. According to the Köppen classification, the region climate is Aw, with well-defined seasons, rainy in summer and dry in winter. Average annual rainfall is $1,549 \mathrm{~mm}$ and the average temperature is $23.6^{\circ} \mathrm{C}$.

The local soil is classified as Quartzarenic Neosol (SANTOS et al., 2014) And has the following chemical properties at the depth of 0-20 cm: $\mathrm{pH}\left(\mathrm{CaCl}_{2}\right)=4.7 ; \mathrm{Al}\left(\mathrm{cmolc} \mathrm{dm}^{-3}\right)=0.24 ; \mathrm{Ca}$ $\left(\mathrm{cmolc} \mathrm{dm}^{-3}\right)=0.75 ; \mathrm{Mg}\left(\mathrm{cmolc} \mathrm{dm}^{-3}\right)=0.10 ; \mathrm{P}(\mathrm{mg}$ $\left.\mathrm{dm}^{-3}\right)=5.6 ; \mathrm{K}\left(\mathrm{mg} \mathrm{dm}^{-3}\right)=14$; cation exchange capacity $(\mathrm{CEC})(\mathrm{cmolc})=2.9$; base saturation $(\%)=$ 30.7 .

In January 2013, during the rainy season, two rubber clones, RRIM 600 and RRIM 937, were planted with spacing of $7.0 \times 2.7 \mathrm{~m}$ in adjacent areas, with similar soil and climatic conditions. The area where the clones were planted has 18.8 hectares, the clone RRIM 600 was planted in 14.7 hectares and RRIM 937 in 4.1 hectares.

In May 2017, 52 months after planting, seven random plots of 21.0 x $32.4 \mathrm{~m}\left(680.4 \mathrm{~m}^{2}\right)$ were set for each clone. Each plot consisted of three planting lines and twelve trees in the line, including the failures. Circumference at breast height $(1.3 \mathrm{~m}$ above the ground, $\mathrm{CBH})$, total height $(\mathrm{Ht})$ of all the trees in the plot and bark thickness (BT) of the trees located in the central line were determined. $\mathrm{CBH}$ measurements were obtained using a measuring tape, Ht was estimated using a Haglof clinometer and BT obtained with a bark meter.

The variables were evaluated for measures of central tendency, variability, asymmetry and kurtosis. Normality was evaluated by ShapiroWilk's test $(\alpha=0.05)$. Equality of variances was evaluated by the F-test $(\alpha=0.05)$ and the averages were compared by the t-test $(\alpha=0.05)$, which considered the equality of variances. The t-test was also performed to confirm if the measures of asymmetry and kurtosis differed from 0 and 3, respectively.

Sample size (n) suitable for each variable in each clone was determined by considering the number of observations performed on each variable for a one half-amplitude of confidence intervals (estimated error) equal to $1,2, \ldots$, and $30 \%$ of the estimated mean (a), with confidence level (1- $\alpha)$, at 95\% probability level. The following expression was used: $\mathbf{\eta}=\frac{t_{\alpha / z} S^{2}}{\varepsilon^{2}}$, wherein: $\mathrm{t}_{\alpha / 2}$ is the critical value of the Student distribution, with (n-1) degrees of freedom, and defined as $\mathrm{P}\left(\mathrm{t}>\mathrm{t}_{\mathrm{a} / 2}\right)=\alpha / 2$ and estimated variance $\left(S^{2}\right)$. All statistical analyses were performed using the Rbio software (BHERING, 2017) and Microsoft Office Excel 2013.

\section{RESULTS AND DISCUSSION}

The t-test revealed a significant difference between the clones for all variables evaluated (Table 1). Clone RRIM 937 presented greater averages than RRIM 600 for all variables. In each of the clones, the $\mathrm{CBH}$ and $\mathrm{Ht}$ variables are correlated $(\mathrm{p}<0.01)$ (RRIM $600-r=0.7634$; RRIM $937-r=0.6236$ ), while the other variable did not correlate ( $p>0.05$ ).

Although there is no information regarding the initial development of the clones evaluated for the studied region, the results obtained for RRIM 600 show a development similar or greater than thase observed for the same clone at 4 years of age in the State of São Paulo (GONÇALVES et al., 1994; 2001; MACEDO et al., 2009). These results are important because they demonstrate that the two clones evaluated have good adaptation to the edaphoclimatic conditions of the region where they were planted, constituting an alternative source of income to the producers.

Latex collection should start when at least $50 \%$ of plants have $\mathrm{CBH}$ of $50 \mathrm{~cm}$ or more and BT equal to or greater than $6 \mathrm{~mm}$ (VIRGENS FILHO, 2014). Therefore, the earlier the trees reach these standards, the more advantageous it will be for the producer, making it important to select for planting those clones that show the best development. Thus, at 52 months, clone RRIM 937 presents more desirable traits for planting, corroborating the results obtained by Gonçalves and Marques (2014). These authors report that, in commercial plantations, the clone RRIM 937 is quite vigorous in the precollection, exceeding RRIM 600 by up to $10 \%$, but after the panel is opened, its growth slows down, and is surpassed by RRIM 600. Thus, it is important to conduct new studies to evaluate the development of these two clones in pre and collection period in the different regions where the rubber tree is cultivated. 
Table 1. Statistical parameters circumference at breast height $(\mathrm{CBH})$, total height $(\mathrm{Ht})$ and bark thickness $(\mathrm{BT})$.

\begin{tabular}{|c|c|c|c|c|c|c|}
\hline \multirow{2}{*}{ Parameter } & \multicolumn{2}{|c|}{$\mathrm{CBH}(\mathbf{c m})$} & \multicolumn{2}{|c|}{$\mathbf{H t}(\mathbf{m})$} & \multicolumn{2}{|c|}{ BT (cm) } \\
\hline & RRIM 600 & RRIM 937 & RRIM 600 & RRIM 937 & RRIM 600 & RRIM 937 \\
\hline$n$ & 249 & 249 & 249 & 249 & 84 & 83 \\
\hline Minimum & 13.50 & 17.40 & 3.80 & 5.50 & 0.09 & 0.10 \\
\hline Maximum & 33.60 & 37.50 & 8.40 & 11.10 & 0.25 & 0.30 \\
\hline $1^{\text {st }}$ quartile & 25.20 & 29.90 & 6.50 & 7.30 & 0.15 & 0.18 \\
\hline $3^{\text {rd }}$ quartile & 28.80 & 33.00 & 7.50 & 8.50 & 0.19 & 0.20 \\
\hline Average $^{1}$ & $26.96^{\mathrm{b}}$ & $31.13^{\mathrm{a}}$ & $6.98^{\mathrm{b}}$ & $7.94^{\mathrm{a}}$ & $0.17^{\mathrm{b}}$ & $0.19^{\mathrm{a}}$ \\
\hline Median & 27.50 & 31.70 & 7.10 & 7.90 & 0.18 & 0.19 \\
\hline Variance $^{2}$ & $8.409^{\mathrm{ns}}$ & $8.363^{\mathrm{ns}}$ & $0.514^{*}$ & $0.884^{*}$ & $0.001^{\mathrm{ns}}$ & $0.002^{\mathrm{ns}}$ \\
\hline Standard deviation & 2.90 & 2.89 & 0.72 & 0.94 & 0.03 & 0.04 \\
\hline $\mathrm{CV}(\%)$ & 10.76 & 9.29 & 10.28 & 11.85 & 20.03 & 20.51 \\
\hline Asymmetry $^{3}$ & $-1.07^{*}$ & $-1.26^{*}$ & $-0.63^{*}$ & $0.26^{*}$ & $-0.71^{*}$ & $0.51^{*}$ \\
\hline Kurtosis ${ }^{4}$ & $2.52^{*}$ & $2.94^{\mathrm{ns}}$ & $0.85^{*}$ & $0.39^{*}$ & $-0.06^{*}$ & $1.32^{*}$ \\
\hline Shapiro-Wilk's 5 & $0.94^{*}$ & $0.92^{*}$ & $0.97^{*}$ & $0.99^{\mathrm{ns}}$ & $0.89^{*}$ & $0.90^{*}$ \\
\hline
\end{tabular}

(1) Averages of each variable measured in each clone followed by the same letter do not differ by the bilateral t-test at 0.05 significance level; (2) * Variances between the clones differ by the F-test at 0.05 significance level; $(\mathbf{3}) *$ Asymmetry differs from zero by the t-test at 0.05 significance level; (4) * Kurtosis differs from three by t-test at 0.05 significance level; (5) * Significant at 0.05 significance level, ns: not significant.

According to Shapiro-Wilk's test, the analyzed variables do not present normal distribution ( $\mathrm{p}<0.05)$, except $\mathrm{Ht}$ for the clone RRIM 937. Overall, these results can be confirmed by the asymmetry and kurtosis coefficients, which mostly differ statistically $(\mathrm{p}<0.05)$ from 0 and 3 , respectively. According to Machado et al. (2006), if the asymmetry coefficient (in modulus) is between 0.15 and 1 , the asymmetry is considered moderate and if it is greater than 1 , the asymmetry is strong. Thus, among the analyzed variables, only $\mathrm{CBH}$ presents strong asymmetry. However, even if the basic population does not present a normal distribution, according to the central limit theorem, the sample mean distribution will be approximately normal for samples larger than 30 observations (BUSSAB \& MORETTIN, 2011). Thus, the data of these variables provide credibility to the scale of the sample size study.

Sample size for estimating the average of each measured variable showed little variation between the clones (Table 2). As the one halfamplitude of the confidence interval increases, there is a reduction in sample size. Considering the one half-amplitude of the confidence interval equal to $1 \%$ of the average estimate, at $95 \%$ probability, the sample size for RRIM 600 varied between 3 and 121 trees, whereas for RRIM 937 the variation was from 4 to 105 trees. Variations of the sample size among different species / clones and among the measured variables were also found by Rosseti et al. (1986), Cargnelutti Filho et al. (2012; 2016), Toebe et al. (2012) and Teodoro et al. (2014; 2015).

From the practical point of view of forest measuration, the results obtained in the present study are consistent, since it is routine in forest inventory procedures done in commercial plantations to measure the diameter (or circumference) of all trees in the plots. For other variables, such as height, which is more difficult to obtain, only part of trees are measured (LEITE \& ANDRADE, 2002; SILVA et al., 2012). Considering the relationship among the ideal sample size for $\mathrm{Ht}$ and $\mathrm{CBH}$, the percentage of trees in which $\mathrm{Ht}$ should be measured in each plot will be $24 \%$ of the trees for RRIM 600 and $41 \%$ for RRIM 937. The remaining trees would have their height estimated by a hypsometric equation. The correlation between the $\mathrm{CBH}$ and $\mathrm{Ht}$ variables indicates that $\mathrm{CBH}$ can be the variable to be used to estimate $\mathrm{Ht}$ by means of a hypsometric relation. 
Table 2. Sample intensity for each variable measured in each clone, according to the acceptable error.

\begin{tabular}{|c|c|c|c|c|c|c|}
\hline \multirow{2}{*}{ Error (\%) } & \multicolumn{2}{|c|}{$\mathrm{CBH}(\mathrm{cm})$} & \multicolumn{2}{|c|}{ Ht (m) } & \multicolumn{2}{|c|}{ BT (mm) } \\
\hline & RRIM 600 & RRIM 937 & RRIM 600 & RRIM 937 & RRIM 600 & RRIM 937 \\
\hline 1 & 121 & 105 & 29 & 44 & 3 & 4 \\
\hline 2 & 61 & 53 & 15 & 22 & 2 & 2 \\
\hline 3 & 41 & 35 & 10 & 15 & 1 & 2 \\
\hline 4 & 31 & 27 & 8 & 11 & 1 & 1 \\
\hline 5 & 25 & 21 & 6 & 9 & 1 & 1 \\
\hline 6 & 21 & 18 & 5 & 8 & 1 & 1 \\
\hline 7 & 18 & 15 & 5 & 7 & 1 & 1 \\
\hline 8 & 16 & 14 & 4 & 6 & 1 & 1 \\
\hline 9 & 14 & 12 & 4 & 5 & 1 & 1 \\
\hline 10 & 13 & 11 & 3 & 5 & 1 & 1 \\
\hline 11 & 11 & 10 & 3 & 4 & 1 & 1 \\
\hline 12 & 11 & 9 & 3 & 4 & 1 & 1 \\
\hline 13 & 10 & 9 & 3 & 4 & 1 & 1 \\
\hline 14 & 9 & 8 & 3 & 4 & 1 & 1 \\
\hline 15 & 9 & 7 & 2 & 3 & 1 & 1 \\
\hline 16 & 8 & 7 & 2 & 3 & 1 & 1 \\
\hline 17 & 8 & 7 & 2 & 3 & 1 & 1 \\
\hline 18 & 7 & 6 & 2 & 3 & 1 & 1 \\
\hline 19 & 7 & 6 & 2 & 3 & 1 & 1 \\
\hline 20 & 7 & 6 & 2 & 3 & 1 & 1 \\
\hline 21 & 6 & 5 & 2 & 3 & 1 & 1 \\
\hline 22 & 6 & 5 & 2 & 2 & 1 & 1 \\
\hline 23 & 6 & 5 & 2 & 2 & 1 & 1 \\
\hline 24 & 6 & 5 & 2 & 2 & 1 & 1 \\
\hline 25 & 5 & 5 & 2 & 2 & 1 & 1 \\
\hline 26 & 5 & 5 & 2 & 2 & 1 & 1 \\
\hline 27 & 5 & 4 & 2 & 2 & 1 & 1 \\
\hline 28 & 5 & 4 & 2 & 2 & 1 & 1 \\
\hline 29 & 5 & 4 & 1 & 2 & 1 & 1 \\
\hline 30 & 5 & 4 & 1 & 2 & 1 & 1 \\
\hline
\end{tabular}

Considering that a sampling error of $10 \%$ is acceptable in forest inventories, a plot with 15 trees would be adequate to characterize the variables measured in the two clones studied, considering this precision level. Thus, a plot consisting of three rows and five trees in the row would be adequate for forest inventory in the studied plantations (Figure 1). This number of trees is similar to that determined by Pimentel-Gomes et al (1989) as suitable to be adopted in experimental plots of rubber tree clones.

It is important to highlight that the sample size can be influenced by several factors, such as site, plant density, silvicultural practices, age and intensity of the exploration, and it is important to determine the plot size for each situation. The influence of age on sample size has already been confirmed by Silva et al. (2003) and Cargnelutti Filho et al. (2012; 2016). Therefore, it is important to keep the appropriate sample size to estimate the variables measured with the advancement of planting ages. 


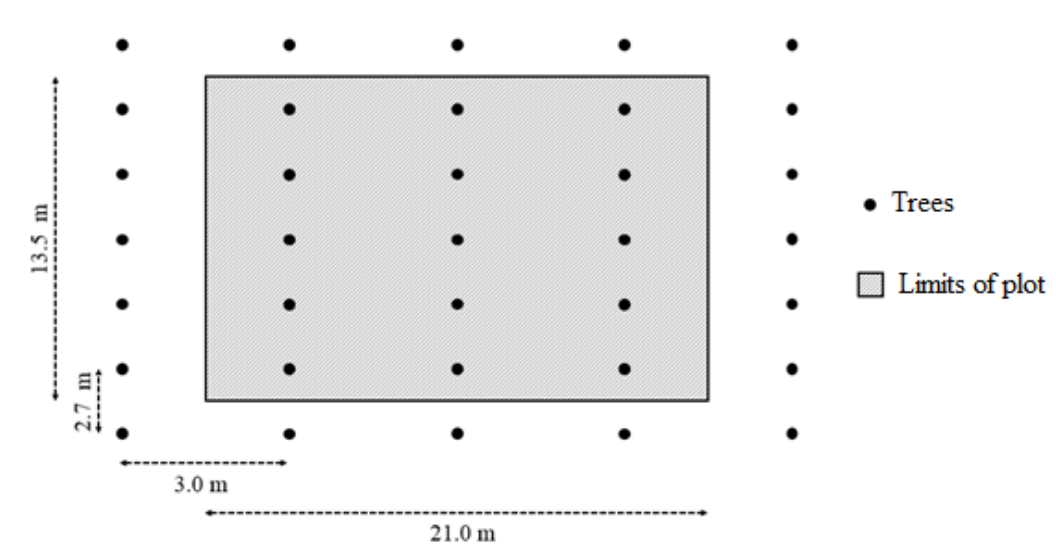

Figure 1. Plot size considering an average error of $10 \%$ for sampling two rubber tree clones (RRIM 600 and RRIM 937), cultivated in the spacing of 7.0 x 2.7 m, in Paraíso da Águas - MS.

\section{CONCLUSIONS}

The ideal sample size is different for the variables in the following order: trunk circumference $>$ total height $>$ bark thickness.

The measurement of plots with 15 trees is adequate to represent the variability of the analyzed variables, considering the acceptable error of $10 \%$. required for this study, and allowing the authors to use his property.

The authors would like to thank the Federal University of Mato Grosso do Sul for their financial support (PROPP Edict 111/2018).

This study was financed in part by the Coordenação de Aperfeiçoamento de Pessoal de Nível Superior Brasil (CAPES) - Finance Code 001.

\section{ACKNOWLEDGEMENTS}

The authors are grateful to Francismar Antônio Pazzini for providing the the information

RESUMO: O sucesso atual do cultivo de seringueira está relacionado ao uso de clones adaptados a diferentes regiões edafoclimáticas. Portanto, é importante avaliar as variáveis que estão correlacionadas com o rendimento. No entanto, um problema comum é escolher as dimensões da área onde essas variáveis serão medidas. Este trabalho foi conduzido com objetivo de avaliar o desenvolvimento inicial de dois clones de seringueira e determinar o tamanho da amostra ideal para caracterizar a circunferência do tronco, altura da árvore e espessura da casca. As variáveis circunferência na altura do peito $(\mathrm{CBH})$, altura total $(\mathrm{Ht})$ e espessura da casca $(\mathrm{BT})$ foram medidas em sete parcelas de $680,4 \mathrm{~m}^{2}$ e foi estabelecido o tamanho da parcela para amostrar satisfatoriamente cada uma das variáveis medidas em cada clone, 52 meses após o plantio. Aos 52 meses, o clone RRIM 937 apresentou melhor desenvolvimento do que RRIM600 em relação às variáveis analisadas. O tamanho ideal da unidade de amostra é diferente para as variáveis na seguinte ordem: circunferência do tronco $>$ altura total $>$ espessura da casca. A medida de parcelas com 15 árvores é adequada para representar a variabilidade das variáveis analisadas, considerando o erro aceitável de $10 \%$.

PALAVRAS-CHAVE: Hevea brasiliensis. Silvicultura. Adaptação de clones.

\section{REFERENCES}

BHERING, L. L. Rbio: A tool for biometric and statistical analysis using the R platform. Crop Breeding and Applied Biotechnology, Viçosa, v. 17, p. 187-190, 2017.

BUSSAB, W.O.; MORETTIN, P.A. Estatística básica. 7.ed. São Paulo: Saraiva, 2011. 540p.

CARGNELUTTI FILHO, A.; ARAUJO, M. M.; GASPARIN, E.; AVILA, L. A. Dimensionamento amostral para avaliação de altura e diâmetro de mudas de Cabralea canjerana. Ciência Rural, Santa Maria, v. 42, n. 7 , p. 1204-1211, 2012. https://doi.org/10.1590/S0103-84782012000700011 
CARGNELUTTI FILHO, A.; BELTRAME, R.; BISOGNIN, D. A.; LAZAROTTO, M.; HASELEIN, C. V.; GATTO, D. A.; SANTOS, G. A. Sample size for estimating average trunk diameter and plant height in eucalyptus hybrids. Ciência Rural, Santa Maria, v. 46, n. 7, p. 1192-1199, 2016. https://doi.org/10.1590/0103$8478 \mathrm{cr} 20140836$

CAVALCANTE, J. R.; CONFORTO, E. C. Caracteres secundários da produção e estado nutricional em dois clones jovens de seringueira em São José do Rio Preto, SP. Revista Biociências, Taubaté, v. 19, n. 2, p. 37-42, 2013.

CONFORTO, E. C.; BITTENCOURT JUNIOR, N. S.; SCALOPPI JUNIOR, E. J.; MORENO, R. M. B. Comparação entre folhas sombreadas de sete clones adultos de seringueira. Revista Ceres, Viçosa, v. 58, n. 1, p. 29- 34, 2011.

CONFORTO, E. C.; SANTOS, J. F.; ZEULI, M. R.; ANDREOLI, R. P. Desenvolvimento inicial de clones IAC de seringueira em São José do Rio Preto, SP. Ciência Rural, Santa Maria, v. 45, n. 7, p. 1235-1240, 2015. https://doi.org/10.1590/0103-8478cr20120443

COSTA, R. B.; GONÇALVES, P. S.; ODALIA-RÍMOLI, A.; ARRUDA, E. J. Melhoramento e conservação genética aplicados ao Desenvolvimento Local - o caso da seringueira (Hevea sp). Revista Internacional de Desenvolvimento Local, Campo Grande, v. 1, n. 2, p. 51-58, 2001.

GONÇALVES, P. S.; BORTOLETTO, N.; FURTADO, E. L.; SAMBUGARO, R.; BATAGLIA, O. C. Desempenho de clones de seringueira da série IAC 300 selecionados para a região noroeste do Estado de São Paulo. Pesquisa Agropecuária Brasileira, Brasilia, v. 36, n. 4, p. 589-599, 2001.

https://doi.org/10.1590/S0100-204X2001000400001

GONÇALVES, P. S.; CARDOSO, M.; CAMPANA, M.; FURTADO, E. L.; TANZINI, M. R. Desempenho de novos clones de Seringueira da série IAC II: Seleções promissoras para a região do planalto do estado de São Paulo. Pesquisa Agropecuária Brasileira, Brasilia, v. 29, n. 8, p. 1215-1224, 1994.

GONÇALVES, P. S.; MARQUES, J. R. B. Clones de Seringueira: Influência dos fatores ambientais na produção e recomendação para o plantio. In: ALVARENGA, A. P.; CARMO, C. A. F. S. Seringueira. 2. ed. Viçosa: EPAMIG Zona da Mata, 2014. cap. VI, p. 249-326.

GONÇALVES, P. S.; ROSSETTI, A. G.; VALOIS, A. C. C.; VIEGAS, I. J. Estimativas de correlações genéticas e fenotípicas de alguns caracteres quantitativos em clones jovens de Seringueira. Revista Brasileira de Genética, Ribeirão Preto, v. 1, n. , p. 95-107, 1984.

LEITE, H. G.; ANDRADE, V. C. L. Um método para condução de inventários florestais sem o uso de equações volumétricas. Revista Árvore, Viçosa, v. 26, n. 3, p. 321-328, 2002.

MACEDO, R. L. G.; VENTURIN, N.; PEREIRA, A.V.; ARAÚJO, P. O. L. C.; VALE, R. S. Estabelecimento e crescimento inicial de clones de Hevea sp na região de Paracatu - MG. Cerne, Lavras, v. 15, n. 1, p. 84-91, 2009.

MACHADO, S. A.; BARTOSZECK, A. C. P. S.; FIGUEIREDO FILHO, A.; OLIVEIRA, E. B. Dinâmica da distribuição diamétrica de Bracatingais na região metropolitana de Curitiba. Revista Árvore, Viçosa, v. 30, n. 5, p. 759-768, 2006.

MUNIZ, J. A.; AQUINO, L. H.; SIMPLÍCIO, E.; SOARES, A. R. Estudo do tamanho de parcelas experimentais em povoamentos de Eucalyptus grandis Hill, usando parcelas lineares. Ciência e Agrotecnologia, Lavras, v. 33, n. 4, p. 1002-1010, 2009. 
OLIVEIRA, L. E. M.; CAIRO, P. A. R.; MESQUITA, L. C.; BONOME, L. T. S.; DELÍ FILHO, N. Assimilação e transporte de carbono e biossíntese de látex em seringueira. In: Alvarenga, A. P.; Carmo, C. A. F. S. Seringueira. 2.ed. Viçosa: EPAMIG, 2014.

PILAU. G. F.; MARIN, F. R.; ASSAD, E. D.; PINTO, H. S.; BARBARISI, B. F.; Zoneamento agroclimático da heveicultura para as regiões Sudeste e Centro-Oeste do Brasil. Revista Brasileira de Agrometeorologia, Santa Maria, v. 15, n. 2, p. 161-168, 2007.

PIMENTEL-GOMES, F.; ROSSETI, A. G.; VIEGAS, R. M. F. Tamanho ótimo de parcelas para experimentação com seringueira. Pesquisa Agropecuária Brasileira, Brasília, v. 24, n. 8, p. 1021-1026, 1989.

RIPPEL, M. M.; BRAGANÇA, F. C. Borracha natural e nanocompósitos com argila. Química Nova, São Paulo, v. 32, n. 3, p. 818-826, mar. 2009. https://doi.org/10.1590/S0100-40422009000300024

ROQUE, C. G.; CENTURION, J. F.; PEREIRA, G. T.; BEUTLER, A. N.; FREDDI, O. S.; ANDRIOLI, I. Mapeamento da produtividade e perímetro de tronco de clones de Seringueira em argissolo vermelho amarelo. Scientia Forestalis, Piracicaba, n. 70, p. 59-66, 2006.

ROSSETTI, A. G.; PEREIRA, A. V.; GOMES, F. P. A amostragem na experimentação em viveiro de Seringueira. Pesquisa Agropecuária Brasileira, Brasilia, v. 21, n. 8, p. 837-841, 1986.

SANTOS, H. G.; JACOMINE, P. K. T.; ANJOS, L. H. C.; OLIVEIRA, V. A.; LUMBRERAS, J. F.; COELHO, M. R.; ALMEIDA, J. A.; CUNHA, T. J. F.; OLIVEIRA, J. B. Sistema brasileiro de classificação de solos. 4. ed. Brasília:EMBRAPA, 2014. 353 p.

SILVA, G. F.; CURTO, R. A.; SOARES, C. P. B.; PIASSI, L. C. Avaliação de métodos de medição de altura em florestas naturais. Revista Árvore, Viçosa, v. 36, n. 2, p. 341-348, 2012.

SILVA, R. L.; XAVIER, A.; LEITE, H. G.; PIRES, I. E. Determinação do tamanho ótimo da parcela experimental pelos métodos da máxima curvatura modificado, do coeficiente de correlação intraclasse e da análise visual em testes clonais de Eucalipto. Revista Árvore, Viçosa, v. 27, n. 5, p. 669-676, 2003.

TEODORO, P. E.; RIBEIRO, L. P.; SILVA, F. A.; CORRÊA, C. C. G.; LUZ JÚNIOR, R. A. A.; TORRES, F. E. Sample size to estimate biomass and productivity of Canavalia ensiformis and Dolichos lablab. Revista de Ciências Agrárias, Lisboa, v. 37, n. 3, p. 348-353, 2014.

TEODORO, P. E.; SILVA JUNIOR, C. A.; RIBEIRO, L. P.; SILVA, F. A.; CORRÊA, C. C. G.; ZANUNCIO, A. S.; TORRES, F. E. Sample Dimension for Estimation of Biomass and Yield of Sunn (Crotalaria juncea L.) and Showy rattlebox (C. spectabilis Roth.). Journal Of Agronomy, New York, v. 14, n. 2, p. 98-101, 2015.

TOEBE, M.; BOTH, V.; BRACKMANN, A.; CARGNELUTTI FILHO, A.; THEWES, F. B. Tamanho de amostra para a estimação da média de caracteres de pêssego na colheita e após o armazenamento refrigerado. Ciência Rural, Santa Maria, v. 42, n. 2, p. 209-212, 2012. https://doi.org/10.1590/S010384782012000200004

VAN LAAR, A.; AKÇA, A. Forest mensuration. Dordrecht: Springer, 2007. 383 p. https://doi.org/10.1007/978-1-4020-5991-9

VIRGENS FILHO, A. C. Organização e exploração do seringal. In: ALVARENGA, A. P.; CARMO, C. A. F. S. Seringueira . 2. ed. Viçosa: EPAMIG Zona da Mata, 2014. cap. V, p. 147-246. 